acetic acid and then treated with ephedrin ${ }^{6} .1 \mathrm{gm}$. of 'Activit' can adsorb about 30-50 mgm. of aromatic dipeptides. Table 4 shows some typical separations.

TABLE 4. SfParations of BINARY miXtures of aliphatic AND

\begin{tabular}{|c|c|c|c|}
\hline \multicolumn{4}{|c|}{ AROMATIC PEPTIDES ON CARBON } \\
\hline Non-adsorbed & $\%$ in & Adsorbed aromatic & $\%$ in eluate \\
\hline $\begin{array}{l}\text { aliphatic } \\
\text { peptides }\end{array}$ & $\begin{array}{l}\text { Hitrate } \\
\text { (i) }\end{array}$ & $\begin{array}{l}\text { Ausoroed aromauc } \\
\text { peptides }\end{array}$ & (i) $\quad$ (ii) \\
\hline Leucyl-glycine & $100 \cdot 8$ & Leucyl-tyrosine & $96 \cdot 8$ \\
\hline Glycyl-leucine & $98 \cdot 3$ & Glycyl-tyrosine & $99 \cdot 8$ \\
\hline Alanyl-glycine & $99 \cdot 8$ & Alanyl-phenylalanine & $100 \cdot 4$ \\
\hline
\end{tabular}

(i), Nitrogen determinations by micro-Kjeldahl; (ii), speciflc determinations by known colorimetric methods.

$0.5 \mathrm{gm}$. of 'Activit $5 O X P$ ' is boiled for $5 \mathrm{~min}$. with $4 \mathrm{ml}$. of 20 per cent acetic acid, filtered, washed with $15 \mathrm{ml}$. hot water, then treated in a beaker with $10 \mathrm{ml}$. water containing $2 \mathrm{mgm}$. of ephedrine; after shaking for $10 \mathrm{~min}$. the carbon is poured into the column (10 mm. diameter) and washed with $15 \mathrm{ml}$. water saturated with hydrogen sulphide. The mixture to be separated (20-30 mgm.) in $5 \mathrm{ml}$. of 5 per cent acetic acid saturated with hydrogen sulphide is filtered on the column, which is then washed with $25 \mathrm{ml}$. of 5 per cent acetic acid saturated with hydrogen sulphide. Non-adsorbed substances are thus washed into the filtrate. The aromatic peptides are eluted with $125 \mathrm{ml}$. of water saturated with ethyl acetate and hydrogen sulphide.

By the methods described above a complex mixture of neutral amino-acids and peptides, such as may result from partial hydrolysis of a protein, can be separated into different groups as shown in the following scheme :

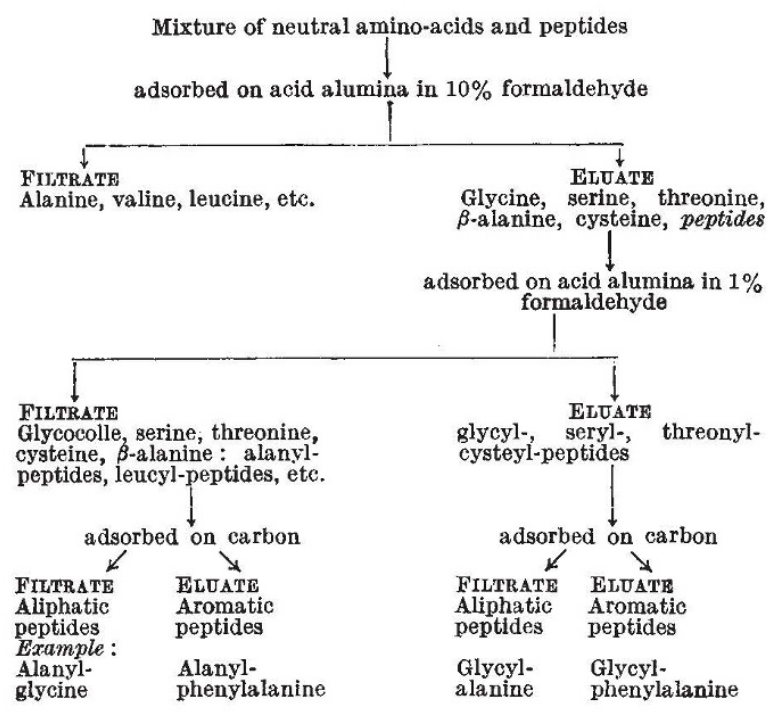

\section{Adsorption of Acid Peptides on Acid Alumina}

Preliminary experiments with glutathione and glycyl-glutamic acid show that acid peptides are quantitatively adsorbed on acid alumina, like glutamic and aspartic acid; elution can be obtained either by acid or, better, by alkali.

All these experiments were done with synthetic di- and tri-peptides; there are reasons to believe that the same methods will be applicable to higher peptides.

Acknowledgments are due to Prof. Cl. Fromageot for his interest in this work, to Dr. H. Pénau
(UCLAF, Paris) for a research fellowship granted to one of us (M. J.), and to Prof. V. Prelog (Zurich), Dr. M. Guggenheim (Basle), and Dr. C. J. Cavallito (Rensselaer, New York), for various synthetic peptides.

${ }^{1}$ Waldschmidt-Leitz, E., and Turba, F., J. Prakt. Chem., 156, 55 (1940). Waldschmidt-Leitz, E., Ratzer, J., and Turba, F., J. Prakt. Chem., 158, 72 (1941).

${ }^{2}$ Gordon, A. H., Martin, A. J. P., and Synge, R. L. M., Biochem. J., 37, 92 (1943).

s Synge, R. L. M., Biochem. J., 38, 285 (1944).

${ }^{4}$ Consden, R., Gordon, A. H., Martin, A. J. P., and Synze, R. L. M., Biochem. J., 40, xliil (1946).

Sent, C. E., Biochem. J., 40, xliv (1946).

- Tiselius, A., The Svedberg Memorial Vol., 370 (1945).

' Lederer, E., and Tchen, P. K., Acta Biochim. et Biophys., 1, 35 (1947).

s Dunn, M. S., and Loshakoff, A., J. Biol. Chem., 113, 691 (1936).

- Schramm, G., and Primosigh, J., Ber., 76, 373 (1943).

${ }^{10}$ Wieland, T., Z. physiol. Chem., 273, 24 (1942).

11 Schramm, G., and Primosigh, J., Ber., 77, 417 (1944).

12 Jutisz, M., and Lederer, E., communication at the 7ème Congrès de Chimie Biologique, Liège, October 6,1946 , in the press.

${ }^{13}$ Wachtel, J. L., and Cassidy, H. G., J. Amer. Chem. Soc., 65, 665 (1943).

14 'Activit', 66 rue d'Auteuil, Paris.

\section{THE TEACHING OF TAXONOMY}

A JOIN'T meeting of the Linnean Society and the A Systematics Association was held in the rooms of the former at Burlington House on February 6, when "The Teaching of Taxonomy" was the subject discussed. Sir Clive Forster-Cooper opened the discussion by noting the wide points of view and urging the importance of modern taxonomy. At one time taxonomy was the foremost branch of biology. It then suffered a decline relative to newer aspects and for a long time was considered a blind alley; but a revival of interest is now occurring. There are dangers in speaking too much of the 'professional' taxonomist, but the museum taxonomist is certainly overburdened in the answering of questions for others and has very little time left for research. It becomes a question whether all the wealth of facts and ideas now tending to be incorporated in taxonomy can be brought together in a unified syllabus for teaching in schools and universities. Sir Clive made the suggestion that the Systematics Association should appoint a com. mittee to draw up some sort of guiding rules, of a sufficiently elastic nature, for the benefit of teachers, and to encourage them to teach students taxonomy along desirable lines.

Prof. James Gray considered it would be a pity if taxonomists should look upon their subject as a Cinderella, for though taxonomy is not the sole basis of biology it can play its part like all other branches in the development of the subject. Tax. onomy must be seen as one of many points of view. Not more than 10 per cent of students of biology become taxonomists, and the problem for the teacher is how he can convey the taxonomic point of view and the discipline of the subject to the other 90 per cent so that they can carry away something which is to them a matter of intellectual pride. The systematist is to a large degree born such, and works much by general impressions. On the whole, the botanist seems to be more fortunate than the zoologist in having workable keys provided for him, and there is a great need in zoology for simple keys that can be used by students and teachers.

Dr. W. B. Turrill urged that plant taxonomy should be taught because it is indispensable to the proper study of every other branch of botany, 
provides admirable material for training in observation, concentration, and record keeping; it is the best means by which students can become familiar with the great wealth of form and the extent of combinations and permutations of characters. Much of the time of professional taxonomists would be saved if more botanists were able to carry out a fair proportion of their own determinations and knew when, and when not, to call in the specialist. That taxonomy is not kept to the forefront in schools and colleges may be because it is a subject in which the teacher can be too easily caught out by his students. Dr. Turrill argued that the best way of giving instruction in taxonomy is by practice with material collected by the student himself. Actual practice in the use and making of keys, descriptions, and illustrations has the double advantage of establishing and increasing interest and in laying a solid foundation for discussion on the principles of classification. When the student is acquainted with sufficient factual data he should be helped to grasp the total of underlying principles and generalizations, and aided in giving them logical form. Through the whole of their course students should be made to go out into the field and garden to collect, handle, dissect, and record their findings for actual specimens which they must learn to classify and dissect. In brief, there are decided limits to the possibilities of the direct adequate teaching of taxonomy, but the student can and should be taught to teach himself taxonomy.

Prof. A. R. Clapham pointed out that plant taxonomy is a branch of botany in its own right and is also a tool for other branches. Yet botany has a unity imposed by its materials. The teacher has to aim at training botanists, and all his students should know something of the methods and principles of taxonomy just as those who become taxonomists should know at least a minimum of facts and prin. ciples in other branches. Taxonomy is not every man's meat. There must be the right mental outlook and a good appreciation of formal characters and of resemblances and differences, that is, a good visual memory. At the University of Sheffield, Prof. Clapham has no course planned solely for taxonomy, but the subject is united with other subjects such as floral biology, cytogenetics, or ecology. Emphasis is placed on the study of species, and examples are taken from the British flora. Small problems are set which may involve taxonomic studies. Taxonomy as a working tool is taught in the field by the study of quadrats and transects. Every year there are one or two students who are much more competent in taxonomy than are other students. These are encouraged to concentrate on the subject. The highest standards are insisted upon.

Prof. H. Boschma (University of Leyden) was introduced by Prof. de Beer as holding the unique position of professor of taxonomic zoology. Prof. Boschma replied to Prof. Gray that the latter's suggestion that identification of plants is easier than that of animals is not true for all groups in either kingdom. He gave some interesting details of the courses in zoology in Leyden. There are two main examinations. In preparation for the first, systematics is taught in association with anatomy; but for the second examination a special subject is chosen, and only a small percentage of students take systematic zoology. The special student is given material on which to work, is introduced to relevant literature, and then has very largely to investigate for himself.
The successful students are the born systematists, and sufficient are selected to fill the vacant posts in museums and other institutions needing specialist taxonomists.

Dr. P. Richards thought that the reputation of taxonomy as a dull subject is due partly to an attempt to teach the results of taxonomy rather than taxonomy as a living branch of research, and partly to academic teaching being too much concerned with the families and larger taxonomic units rather than with species and intra-specific units. The characters of, for example, a family are extremely abstract. He described an experiment tried recently at Cambridge in which every advanced student makes, with some help and guidance, a thorough study of the taxonomy of a single variable species or of two or three closely related species, in the field, the laboratory, and the herbarium. The results have shown that the method is very successful in stimulating interest and in giving insight into the real nature of taxonomy. Dr. Richards also suggested that the teaching of taxonomic botany should not be based entirely on the flowering plants. In particular, mosses and liverworts provide excellent material, available at any time of the year, for the teaching of taxonomy. $\mathrm{He}$ also urged the need for a text-book of plant taxonomy covering the whole field. He suggested that the Systematics Association should initiate or encourage the writing of such a book.

Prof. A. E. Trueman referred to the point of view of the palæontologist and to the great difficulties of identification owing to the very great wealth of past life now known. More and more species and genera are having to be accepted. Whether it be studied for applied purposes or as part of the philosophy of biology, all kinds of taxonomic research and training are involved in palæontology.

Prof. A. G. Tansley agreed that a systematist must be born and endowed with a good visual memory. $\mathrm{He}$ stressed the importance of students working at individual species rather than being given abstract accounts of families. A student cannot build up a sound taxonomic knowledge unless he gets to know species in the field and herbarium.

Dr. S. P. Wiltshire stressed the need in plant pathology for training in the procedure of identification of fungi. The correct identification of pathogenic fungi is essential in order to make the relevant literature available. Yet many supposedly fully trained mycologists from the universities have never seen the inside of a herbarium packet or looked at the rules of nomenclature.

Mr. A. J. Wilmott said that by the study of one particular example of name change, if sufficiently complicated, all sorts of methods and bases of systematic work can be understood.

Dr. G. S. Carter considered that biology is now part of the schoolboy's work and has, therefore, less interest for him. Students should be encouraged to take up the problems of classification of small groups. This would make them realize what a species is.

Prof. I. Manton pointed out that many provincial teaching institutions have no great national collection of plants near at hand. She suggested that the Systematics Association might well arrange a course for precise training in herbarium methods.

Dr. O. W. Richards asked that universities should employ entomologists on their staffs and have entomology recognized as a degree subject.

The president of the Linnean Society, Prof. G. R. de Beer, in summing up the results of the discussion, 
gave examples of the high cost of a lack of knowledge of taxonomy. It had been clearly shown that there is a wide recognition of the value of taxonomy and that more of it is wanted. When the Linnean Society was founded, taxonomy was the most prominent aspect of biology, and ever since, symposia on taxonomic subjects have been a recurring feature of its meetings. This shows the perennial value of taxonomy as an intellectual discipline. The Society itself is the custodian of important taxonomic collections, and the Council is fully prepared to co-operate in the giving of instruction in taxonomic principles.

\section{FORTHCOMING EVENTS}

\section{Wednesday, April 9}

Insiritute of PetroledM (at Manson House, 26 Portland Place, London, W.1), at 5.30 p.m.-Dr. H. Steiner: "Aromatics from Petroleum".

Thursday, April 10

Institution of CHEMICAL ENGINEeRs (at the Connaught Rooms, Great Queen Street, London W.C.2), at 11 a $m$.T Twenty-fifth Annual Meeting; at 12 noon-Mr. Hugh Griffiths : "Crystallisation".

INSTITUTION OF ELECTRICAL ENGINEERS (at Savoy Place, Victoria Embankment, London, W.C.2), at 5.30 p.m.-.Mr. C. T. Melling : "Commercial Development of Electricity Supply as a Consumer Service".

ILluminating EngINeERING SOCIETy, MaNChester Centre (in the Reynolds Hall, College of Technology, Manchester), at 6 p.m.Mr. W. J. Wellwood Ferguson: "Lighting in Coal Mines".

ROYAL AERONAUTICAL SOCIETT (at the Institution of Civil Engineers Great George Street, Iondon S.W 1), at 6 p.m Mr. Civil Fielding: "A Review of Production Difficulties in Relation to Aircraft Design".

WOMEN'S ENGINEERING SOCIETY, MANCKESTER BRANCH (at the Engineers' Club, Albert Square, Manchester), at 6.30 p.m.-Dr. N. H. Searby : "Television".

Wednesday, April 9-Thursday, April 10

FARADAY SOCIETY (in the Chemistry Department, The University, Manchester) - General Discussion on "Electrode Processes".

Wednesday, April 9

At 10 a.m.-General Discussion.

Thursday, April 10

At 10 a.m.-General Discussion.

Institution of Electronics, N.W. ENGLAND SEction (in the Great Hall, College of Technology, Manchester).--Annual General Meeting and Second Annual Exhibition.

Wednesday, April 9, at 6.30 p.m.

Thursday, April 10, at 2.30 p.m.

Mathematical Association (at the Polytechnic, 309 Regent Street, London, W.1).-Annual General Meeting.

\section{Wednesday, April 9-Saturday, April 12}

Physical Socrety (at Imperial College, Imperial Institute Road, London, S.W.7), at 10 a.m.- -Thirty-first Exhibition of Scientific Instruments and Apparatus.

Thursday, April 10-Tuesday, April 15

BRITISH PSYchologICAL SocieTx (at the Bergman Österberg Physical Training College, Dartford Heath, Kent).-Annual General Meeting.

Mr. R. J. Bartlett: "Mind" (Presidential Address), at 5 p.m. on April 12.

Friday, April II

Textrue Instrutue- (at 16 St. Mary's Parsonage, Manchester), at 1 p.m.-Mr. C. Garrett : "The Bleaching and Subsequent Dyeing Jute Fabrics"

BIOchamical Society (at the Rowett Research Institute, Bucksburn, Aberdeen), at 2.30 p.m.- Scientiflc Papers and Demonstrations.

ROYal Astronomical Societry (at Burlington House, Piccadilly, London, W.1), at 4.30 p.m.-Scientiflc Papers.

OIL AND Colour CHeMists' Association, Manchester ShCtion (at the Engineers' Club, Albert Square, Manchester), at 6.30 p.m.Annual General Meeting.

Paper Makers' Association, Northrern Division (at the Engineers' Club, Albert Square, Manchester), at 7 p.m.-Discussion on "From Press to Reel End"'

SheFfTeld METAXluRgical Association, Modern Methods of ANALYSIS GRodP (at 198 West Street, Sheffield), at 7 p.m.--Mr. G. Robinson: "Metallurgical Chromatography".

SOCIETY OF DYERS AND ColourIsts (at St. Enoch Hotel, Glasgow), at 7 p.m.-Dr. G. L. Royer : "The Application of Microscopy to the Textile Field".

\section{Saturday, April 12}

BRITISH INTRRPLANETARY SOCIETY (at the Science Museum, Exhibition Road, London, S.W.7), at 6 p.m.-Mr. Lionel Gilbert "Cosmic Rays".

\section{APPOINTMENTS VACANT}

APPLICATIONS are invited for the following appointments on or Afore the dates mentioned :

LABORATORY STEWARD (Grade D) IN THE DEPARTMENT OF BOTANY The Professor of Botany, The University, Leeds 2 (April 8).

SCIENTIFIC OFFICER as ASSISTANT IN THE OPERATIONAL RESEARCH SECTION (University degree in Chemistry, Biology, Physics or Mathematics essential)-The Personnel Officer, British Iron and Steel Research Association, 11 Park Lane, London, W.1, endorsed 'Operational Research Section' (April 12).

DIRECTOR OF THE SCrence DePARTMENT-The Director, Appointments Department, British Council, 3 Hanover Street, London, W. (April 15).

SENIOR LECTURER, and a LECTURER, IN THE DEPARTMENT OF ANATOMY - The Secretary, St. Mary's Hospital Medical School, Paddington, London, W.2 (April 15)

LECTURER IN THE DEPARTMENT OF GEOLOGY - The Secretary, Bed ford College for Women, Regent's Park, London, N.W.1 (April 24). LECTORER with qualifications in Pure Mathematics, a LECTURE with qualifleations in Applied Mathematics, and an AssisTAN LECTURER with qualiflcations in Pure or Applied Mathematics-The Registrar, The University, Manchester 13 (April 24).

LECTURER (Grade III) IN THE DRPARTMENT OF ELECTRICAI ENGINEERING (Electrotechnics) -The Registrar, The University, Liverpool (April 26).

CHIFF PHARMAcist to the Ministry of Health-The Director of Establishments, Ministry of Health, Whitehall, London, S.W.1 (April 26).

.c. Research Fellowships (3) IN Chemistry or Physics, or some allied subject such as Biochemistry, Colloid Science, Chemotherapy, Pharmacology, Metallurgy or Engineering-The Registrar, The University, Liverpool (April 30).

PROFESSOR OF PATHOLOGY in the Medical School, Dundee, and PATHOLOgIST and CLINICAL PATHOLOGIST to the Dundee Roya Inflrmary (associated appointments)--The Secretary, The University, St. Andrews (April 30).

LECTURER IN Mathematics, and a Lecturer in Mathematical PHYSICS-The Secretary, Queen's University, Belfast (May 1). TECHNICran in the Dental Hospital of the University of BristolThe Professor of Pathology, Canynge Hall, Bristol 8 (May 1). LECTORER IN SOCIAL PSYCHOLOGY-The Registrar, The University Leeds 2 (May 1).

Professor of Metallurgy-The Registrar, University College, ingleton Park, Swansea (May 3).

READERSHIP IN PORE MATHFMatics tenable at King's College-The Academic Registrar, University of London, Senate House, London, W.C.1 (May 13).

LeCturer IN HUMaN PHYsiology-The Secretary, St. Mary's Hospital Medical School, Paddington, London, W.2 (May 15).

METALLURGIST with industrial or research experience of foundry work, a M.ETALLORGIST for independent research work on non-ferrous work, a METALLURGIST for independent research work on non-forrous
metal foundry problems, and METALLURGSTS (2) for the Liaison and Technical Service Department-The Secretary, British Non-Ferrous Metals Research Association, Euston Street, London, N.W.1.

LABORATORY STEWARD (biology) - The Head of the Department of Chemistry and Biology, The Polytechnic, 309 Regent Street, London, W.1.

Assistant Teghnical Secretary in the Metalilurgy DivisionThe Personnel Officer, British Iron and Steel Research Association, 11 Park Lane, London, W.1 (endorsed 'Metallurgy Division') AsSISTANT BrodHemist at the Courtauld Institute--The Medical School Secretary, Middlesex Hospital, London, W.1.

LEOTURER IN GEOGRAPHY, a LECTURER IN PURE MATHEMatros, a LECTURER IN ORGANIC CHEMISTRY, a LECTURER IN PHYSICS, and an ASSISTANT LEOTURER XN CHEMISTRX-The Registrar, University College, Leicester.

TECHNICAL RESEARCH ASSISTANT (well qualitied) for nutritional research-The Secretary, King's College of Household and Socia Science, Campden Hill Road, London, W. 8 .

SENIOR LECTORER IN MATHEMATICS-The Secretary, Royal Technical College, Glasgow.

RESEARCH CHEMIST-The Director of Research, Rese arch Associatio of British Flour Millers, Cereals Research Station, Old London Road. St. Albans.

TECHNICAL INDEXER on the staff of the Plant and Animal Products Department--The Establishment Officer, Imperial Institute, South Kensington, London, S.W.7.

PHYSICrST with considerable knowledge of rubber technology, for esearch and development on the engineering applications of rubber, PHYSICIST to work on fundamental aspects of rubber elasticity, PHYSICAX CHrors to work on the kinetics of oxidation, and an Pron - The Strotsy 19 Fenchurch Street, London, E.C.3.

CHFMIST, a BOTANIST, and an AGRICULTURIST, in the Intelligence CHFMIST, a BOTANIST, and an AGRIC Section of the Plunt and Animal sroduets Department-The Establ.

CHEMIST or BIOCHEMIST to assist in isolation of substances biological interest from natural sources-The Professor of Pathology, Sir William Dunn School of Pathology, Oxford.

ANATOMY DISSEOTING-ROOM ATTENDANT, and a LABORATORY STEWARD (experienced) with knowledge of physics and laboratory administration-The Secretary, King's College, Strand, London, admin

W.C.2. METEOROLOGICAL OFFIOKRS IN MALAYA-The Director
ment, Colonial Service, 15 Victoria Street, London, S.W.1.

ment, Colonial Service, 15 Victoria Street, London, S.W.1.
LABORATORY TECHNICIAN-The Medical Superintendent, St. Luke's LABORATORY TECHNICI
Mospital, Middlesbrough. 